\title{
PREFACE
}

\section{DEDICATED TO DR. H. C. MULT. PROF. ING. FRANTIŠEK TREBUŇA, CSC. ON THE OCCASION OF HIS 70 ${ }^{\text {TH }}$ BIRTHDAY}

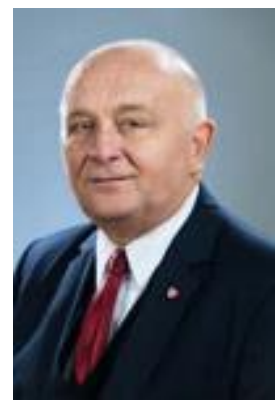

\author{
BOCKO Jozef ${ }^{1}$, JANČO Roland ${ }^{2}$, HUČKO Branislav² \\ ${ }^{1}$ Technical University of Košice, Faculty of Mechanical Engineering, Department of Applied Mechanics and \\ Mechanical Engineering, Letná 9, 04200 Košice, Slovak Republic, email: jozef.bocko@tuke.sk \\ ${ }^{2}$ Slovak University of Technology in Bratislava, Faculty of Mechanical Engineering ,Institute of Applied \\ Mechanics and Mechatronics, Nám. Slobody 17,812 31 Bratislava, Slovak Republic, email: \\ roland.janco@stuba.sk,branislav.hucko@stuba.sk
}

\begin{abstract}
The article deals with the contribution of Dr.h.c. mult. prof. Ing. František Trebuňa, CSc to the field of engineering. Born in 1947, he studied and subsequently remained at the Faculty of Mechanical Engineering, Technical University of Košice since 1965. Under his leadership 25 dissertation theses were defended in the study programs Applied mechanics, Mechatronics and Forensic engineering. He is author to 14 monographs, 16 textbooks, 5 other books, 12 university textbooks and more than 350 original scientific papers published in domestic and foreign journals and conference proceedings. Professor Trebuňa is currently the dean at the faculty and is known as a gifted educator.
\end{abstract}

Dr.h.c. mult. prof. Ing. František Trebuňa, CSc. (1947) was born in Spišské Hanušovce. After finishing High School in Spišská Stará Ves he enrolled at the Faculty of Mechanical Engineering, Technical University of Košice, in 1965 where he graduated with honors in 1971 specializing in Technology of Mechanical Engineering. After graduation he worked at the Department of Technical Mechanics and Elasticity as an assistant. From 1971-1973 he was internal aspirant on the Department of Applied Mechanics under the leadership of prof. Ing. Alexander Doktor. In 1978 he defended his thesis "Application of mathematical theory of elasticity for computation of orthotropic plates and structures", branch: "Mechanics of solid and deformable bodies and environments" at the Faculty of Mechanical Engineering, Technical University of Košice and habilitated to the position of associated professor. 
Prof. Trebuña became a professor in the field of applied mechanics in 1995 with the inauguration lecture „Analytical and experimental assessment of strength and stiffness in supporting structures made of classical and advanced materials“.

From 1995-1997 he was vice-dean for research and development activities at the Faculty of Mechanical Engineering, Technical University of Košice. From 1997 to 2003 he was dean of faculty over two function periods. In 2003-2011 prof. Trebuňa was vice-dean at FME TUKE and since 2011 has again become dean.

Over the years managing the faculty, prof. Trebuna actively participated in the development and propagation of machinery, which has led to acknowledgment of his work by numerous accolades. Just recently, he has received honors at the International Trade Fair in Nitra pertaining to excellence in Shell Eco-marathon competition and so on.

Under the leadership of prof. Trebuňa, a new Prototype and Innovation Center was built. The center is intended to become a top-level workplace not only in Slovakia, but also in the world. In 2015 he established the Institute of Automation, Mechatronics and Robotics which played an important role in the decision of the company Minebea to establish a new production and research center for the automotive industry in Košice. His faculty competed in this matter with several universities. Minebea has a plan to create approximately 100 jobs for researchers together with the Faculty of Mechanical Engineering, Technical University of Košice.

In 2017 the FME TUKE has gained, as one of two universities in Slovakia, international accreditation in the study program Mechanical engineering. This will ensure a better position for students entering the market as well as the acceptance of diplomas by reputable foreign universities.

Prof. Trebuňa has devoted all his professional career to research and education of professionals in the field of mechanical engineering. Under his leadership 25 dissertation theses were defended in the study programs Applied mechanics, Mechatronics and Forensic engineering. Prof. Trebuňa has taken part in several foreign lecturers and study workshops.

Prof. Trebuňa is specialized in the computational methods of thin-walled structures and their experimental verification, strength and stiffness analyses of robots and manipulators, development of methods of experimental stress analysis, development of non-classic experimental procedures for deformation and stress analysis in supporting members of mechanical as well as mechatronic systems with emphasis on using optical methods, assessment of lifespan and safe operation of machines and equipment.

The scientific and research activities of Dr.h.c. mult. prof. Ing. František Trebuňa, CSc. were, also at the time of his studies, oriented to technologies that could be evaluated as 
innovative at the time. Under his leadership several domestic as well as foreign research projects, state research tasks, important engineering projects and apprenticeships were successfully performed. Within the sphere of scientific development activities he contributed to the establishment of new methods in computation and verification, new technical solutions of machines and equipment, applications of new materials with the intent to implement new knowledge into the solution of practical tasks. A noteworthy contribution part of his contributions whould also be his cooperation with companies and industries within Slovakia which were oriented to creating new engineering jobs, solution of serious accidents and practical problems in the fields of mechanical engineering (U. S. Steel Košice), power supply including nuclear (JAVYS, Eustream, Slovenské elektrárne), metallurgy and mining. All methodologies that were established throughout his research tasks were intended to be applied in the solution of common engineering practices. Prof. Trebun̆a has contributed over 300 Novel engineering works including methodologies that were realized in practice.

Prof. Trebuňa is author to 14 monographs, 16 textbooks, 5 other books, 12 university textbooks and more than 350 original scientific papers published in domestic and foreign journals and conference proceedings.

Prof. Trebuňa is a member of several domestic and foreign scientific boards, a consistent member of editorial boards in scientific and professional journals. He is the chairman of the faculty commission for doctoral study in the study program Applied mechanics.

The pedagogical, scientific and managerial activities of prof. Trebuňa have been acknowledged by many important honors. The most important of which were: Czechoslovak Academy of Sciences, Certificate of merit, Prague (1971), Medal of Georg Agricola VŠB TU Ostrav (2002), Gold medal VUT Brno (2002), Commemoration at the STU Bratislava (1999), Gold medal TU Košice (1997), honors from the Slovak literary fond (1986), including one monograph in 2000 which brought him recognition as an outstanding intellectual in the 20th Century, International Biographical Centre Cambridge, England, 2001, Gold medal for Slovakia from ABI in USA, Teacher of the year in 2007 from IBC Cambridge, several acknowledgments for best textbook, many domestic and foreign appraisals from scientific institutions, universities and throughout industry. The most important of which were honorable doctorates from VUT Brno (2005), VŠB - TU Ostrava (2007) and Trečín University of AD in Trenčín (2008), the prize Honorary Doctorate of Letters (For the extraordinary contribution in the area of creation, development and publication activity in the scientific branches of applied mechanics and mechatronics), IBC Cambridge, England, 2013, The Gold Medal of Maximilian Hell, TnU AD in Trenčín, (2016). Prof. Trebuňa has been awarded also by the Order of L'udovít Štúr II. class (2014) for outstanding merit and lifetime achievement in the field of education, science, technique and for excellent presentation 
throughout the Slovak republic and abroad. This accolade was awarded in a solemn ceremony in the Knights Hall of Bratislava castle.

Professor Trebuňa is a gifted educator. He has always given his students the utmost support and inspires enthusiasm. To be his student was a great reward. To celebrate Professor Trebuňa's 70th birthday, we dedicate this special issue of the AMS to him. There are a number articles in this issue which have been contributed by his former students, colleagues, and friends. We are grateful to all authors who have endeavored to bring about a refreshing novelty in this special issue. 